\title{
Evaluation of the behavior of dairy calves bred in tropical climate
}

\author{
Avaliação do comportamento de bezerros leiteiros em clima tropical \\ Evaluación del comportamiento de los terneros lecheros en un clima tropical
}

Received: 02/14/2021 | Reviewed: 03/22/2021 |Accept: 03/07/2021 | Published: 03/19/2021

\author{
Dariane Fontes da Silva \\ ORCID: https://orcid.org/0000-0002-7274-8769 \\ Federal University of Paraiba, Brazil \\ E-mail: dari.bans@hotmail.com \\ Alberto Jefferson da Silva Macêdo \\ ORCID: https://orcid.org/0000-0002-2789-0221 \\ Federal University of Viçosa, Brazil \\ E-mail: alberto.macedo@ufv.br \\ Amanda Silva de Lima \\ ORCID: https://orcid.org/0000-0002-9489-2892 \\ Federal Rural University of Pernambuco, Brazil \\ E-mail: amandanupam@gmail.com \\ Anderson Antônio Ferreira da Silva \\ ORCID: https://orcid.org/0000-0001-7329-2989 \\ Federal University of Campina Grande, Brazil \\ E-mail: andersometeorologia@gmail.com \\ Maycon Souto Gomes \\ ORCID: https://orcid.org/0000-0002-9014-4790 \\ Federal University of Paraiba, Brazil \\ E-mail: mayconzootecnista@gmail.com \\ Eduardo Henrique Santos de Lima \\ ORCID: https://orcid.org/0000-0002-9147-3940 \\ Federal University of Campina Grande, Brazil \\ E-mail: eduardohsantosdelima@gmail.com \\ Márcia das Neves Soares \\ ORCID: https://orcid.org/0000-0001-9099-4181 \\ Federal University of Viçosa, Brazil \\ E-mail: marciazootecnia19@gmail.com \\ Thaiano Iranildo de Sousa Silva \\ ORCID: https://orcid.org/0000-0001-5137-1299 \\ São Paulo State University Júlio de Mesquita Filho, Brazil \\ E-mail: thaianosousas@gmail.com \\ Vinícius de França Carvalho Fonsêca \\ ORCID: https://orcid.org/0000-0001-5842-1041 \\ University of the Witwatersrand, South Africa \\ E-mail:vinicius_fonseca86@hotmail.com \\ Edilson Paes Saraiva \\ ORCID: https://orcid.org/0000-0001-9461-1723 \\ Federal University of Paraiba, Brazil \\ E-mail: edilson@cca.ufpb.br
}

\begin{abstract}
The purpose of this study was to evaluate the behavior of dairy calves bred in tropical climate. Six calves of the Girolando breed at 3 months old in average were used. For the elaboration of the ethogram, the focal animal sampling method was used for five days. The Analysis of Variance was run and treatment means were compared by Tukey's test at 5\% probability. Findings show that calves spent more time in the concentrate intake and foraging, the rumination occurred more frequently during the night, and no significant differences were found between the water intake and the leisure activity. The thermoregulation behavior regarding the shadow demand did not differ statistically when compared to the sun rays demand. However, animals remained in the standing position for longer in the afternoon, and spent more time walking in the morning. Statistical differences were found between the playing interaction 1 and the playing interaction 2 , and there were no statistical differences between the stereotypy and vocalization. Therefore, the behavioral states were found to be indicators of the good welfare degree for calves kept in a tropical breeding system.
\end{abstract} Keywords: Animal welfare; Argentine calf; Dairy cattle; Stereotypy; Interaction. 


\begin{abstract}
Resumo
Objetivou-se com esse estudo avaliar o comportamento de bezerros leiteiros criados em clima tropical. Foram utilizados seis bezerros da raça Girolando com idade média de três meses. Os animais foram observados de forma direta (animal focal) durante cinco dias e seus comportamentos foram registrados em etograma. Os dados foram submetidos à análise de variância e as médias comparadas pelo teste de Tukey a 5\% de probabilidade. Diante das análises realizadas, observou-se que os bezerros passaram mais tempo nas atividades de ingestão de concentrado e forrageamento. Os animais realizaram ruminação predominantemente à noite. Não foram observadas diferenças estatísticas entre as atividades de ingestão de água e ócio. O comportamento de termorregulação, avaliado pela procura por sombra e sol não diferiram estatisticamente. No entanto, os animais permaneceram mais tempo na posição em pé durante o período da tarde. Os animais passaram mais tempo caminhando na parte da manhã. Houve diferença estatística no comportamento de interação brincar 1 e brincar 2. Não houve diferença estatística para as variáveis estereotipias e vocalização. Concluiu-se que os estados comportamentais foram indicadores de um grau de bem-estar bom, para os bezerros mantidos em sistema tropical de criação.
\end{abstract}

Palavras-chave: Bem-estar animal; Bezerreiro tropical; Bovino de leite; Estereotipias; Interação.

\title{
Resumen
}

El objetivo de este estudio fue evaluar el comportamiento de terneros lecheros criados en un clima tropical. Se utilizaron seis terneros Girolando con una edad promedio de tres meses. Los animales se observaron directamente (animal focal) durante cinco días y su comportamiento se registró en un etograma. Los datos se sometieron a análisis de varianza y las medias se compararon mediante la prueba de Tukey al 5\% de probabilidad. A la vista de los análisis realizados, se observó que los terneros pasaban más tiempo en las actividades de ingestión de concentrado y forrajeo. Los animales rumiaban predominantemente por la noche. No se observaron diferencias estadísticas entre actividades acuáticas y de ocio. El comportamiento de termorregulación, evaluado mediante la búsqueda de sombra y sol, no difirió estadísticamente. Sin embargo, los animales permanecieron en posición de pie más tiempo durante la tarde. Los animales pasaron más tiempo caminando por la mañana. Hubo una diferencia estadística en el comportamiento de interacción de jugar 1 y tocar 2. No hubo diferencia estadística para las variables de estereotipo y vocalización. Se concluyó que los estados de comportamiento eran indicadores de un buen grado de bienestar, para los terneros mantenidos en un sistema tropical de crianza.

Palabras clave: Bienestar animal; Ternero tropical; Vacas lecheras; Estereotipos; Interacción.

\section{Introduction}

The topic about animal behavior and welfare in Brazil was little understood and studied few years ago. This is the reason why there was no much concern regarding environmental conditions where animals were bred, the way how they were managed, even if their basic needs for the maintenance of vital functions were being attended.

However, a greater concern has emerged from the current state of understanding of the animal health and welfare, as well as from the interest of the society. This trend contributed to the increase of the importance of the biological and physiological knowledge, and the natural behavior of species, so that the animal health and welfare are not affected.

The state of the animal usually interferes directly in its life quality, thus compromising its welfare and putting at risk the quality of animal origin products such as milk, meet and eggs. On other hand, it is essential for consumers that beef animals live relatively in natural environment to allow them expressing their innate behaviors.

Taking into consideration concerns regarding the animal welfare aspects, analyses on the effect caused to the behavior of dairy calves bred individually, with no social contact to each other, were carried out. This made the European Union to prohibit the individual breeding system for calves at over 8 weeks old, thus showing that the group breeding system of calves allow natural social interaction among them. Besides, animals bred in group are found to be more active, favoring desirable behaviors and increasing productivity rates (Oliveira et al, 2005; Von Keyserlingk et al., 2009).

Understanding the needs and the behavior of bovines becomes complex, once there is a literary scarcity of the behavioral biology regarding such species. Scientific studies bring new perspectives and afford the comprehension of mistaken situations (Façanha et al., 2011).

However, the characterization of behavioral and feeding patterns of dairy calves is found to be important, since they are related to the animal health and welfare. Establishing such patterns becomes relevant in the decision making process 
regarding nutrition and management of animal production systems (Svensson \& Jensen, 2007; Carneiro et al., 2020).

The study aims at evaluating the animal behavior of dairy calves kept in a tropical breeding system.

\section{Methodology}

The experiment was conducted in December 2014 in the Dairy Cattle Section of the Center of Agrarian Sciences at the Federal University of Paraiba - Campus II, Areia - PB, located in the Brejo Paraibano Microregion, at 618 elevation, 1,400 $\mathrm{mm}$ average rainfall per year, and temperature from $12^{\circ} \mathrm{C}$ to $31^{\circ} \mathrm{C}$. According to data obtained from the Weather Station of the Center of Agrarian Sciences, the average of the air temperature in the study area rounded at $25.5^{\circ} \mathrm{C}$ during the assessment period.

The study accomplished rigorously the existing international norms regarding animals use in research, also complying with the law on animal welfare.

Six calves of the Girolando breed at 3 months old in average, 4 males and 2 females, were used for behavioral assessment. Animals were submitted to the adaptation period for one day, followed by 5 days for data collection. Data regarding the behavior were recorded on a specific ethogram for the animal category under study.

Animals were arranged in an argentine-type calf (shadow-net at north - south direction) with availability of individual shelters (east - west). This breeding system allowed the access for sun rays inside the whole calf area, thus reducing the existing humidity from animal feces and urine on the ground, and minimizing the proliferation of pathogenic microorganisms, causal agents of diarrhea and breathing problems. This breeding system model also allowed the availability of wide space for animals locomotion, thus prevent them from doing physiological needs in the same ground within the facility.

Each animal was restrained with a collar connected to a chain 1.5 meters length tied to a steel wire 10 meters length, supported by two poles (Figure 1,A,B). A total of $72 \mathrm{~m}^{2}$ shadow-net ( $24 \mathrm{~m}$ length $\times 3 \mathrm{~m}$ width) were available for the six animals, where each animal was in $12 \mathrm{~m}^{2}$ area ( $4 \mathrm{~m}$ length $\times 3 \mathrm{~m}$ width) (Figure 2). Individual houses and the steel wire were at north - south direction. Animals had access to the shadow and sunny areas, allowing them to interact to each other, also having physical contact either from the right side or left side.

Figure 1. Arrangement of animals at the experimental site.

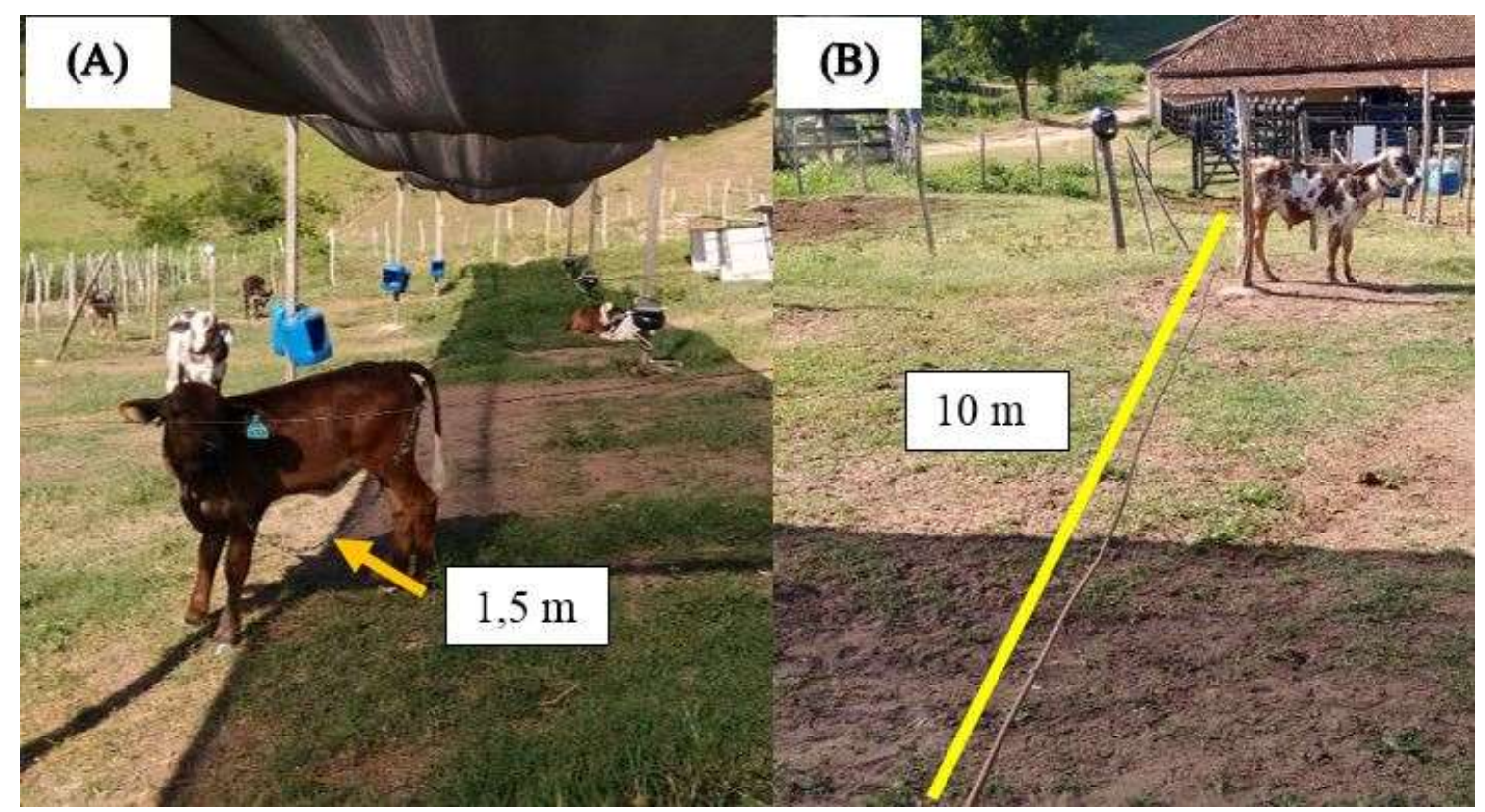

Source: Authors. 
Figure 2. Measurement of the argentine-type calf.

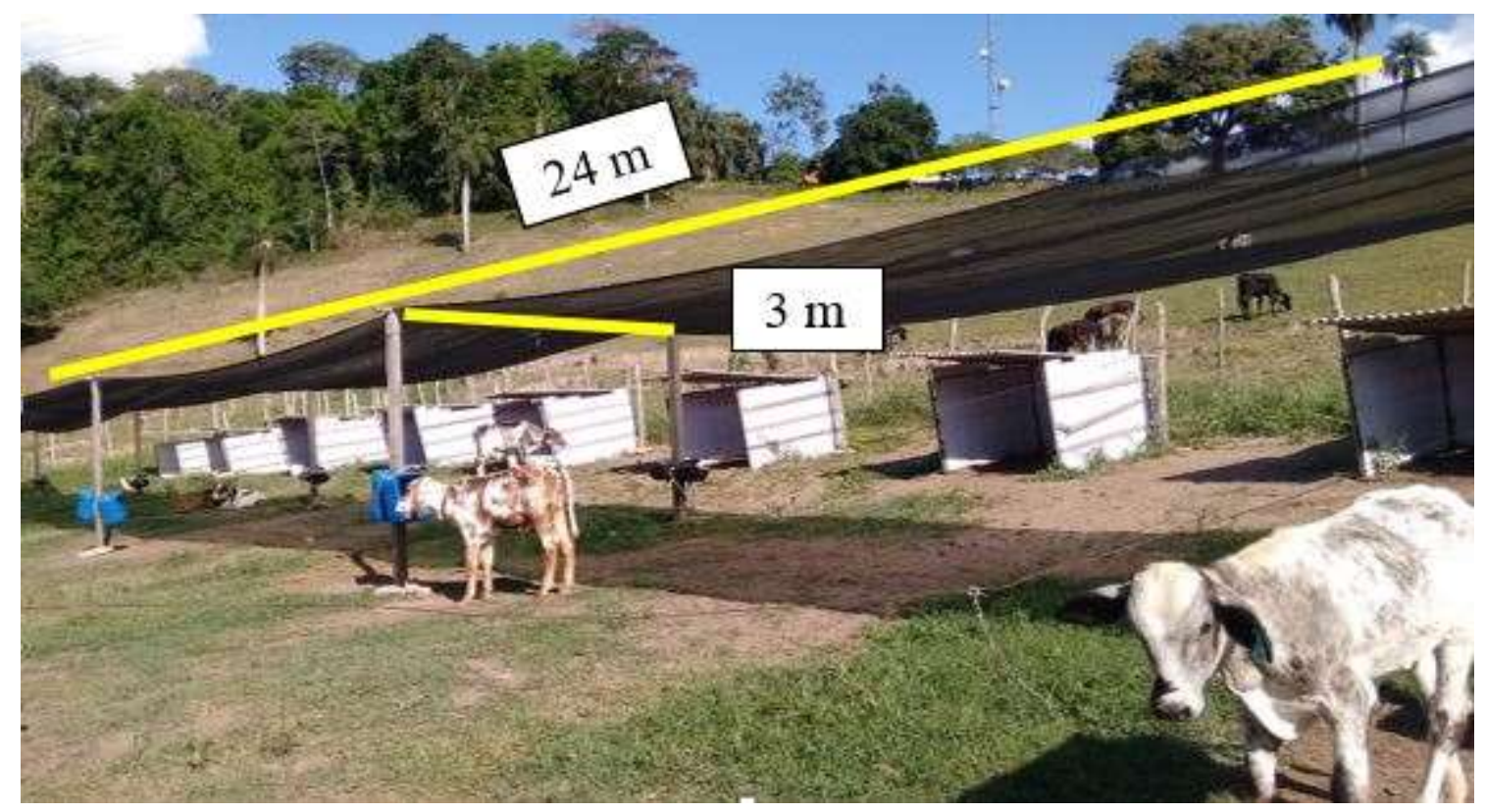

Source: Authors.

Individual drinking fountains and feeders were provided to each animal during the experimental period. The supply of liquid feed (succedaneum) was done twice a day at 08:00 a.m. and 3:00 p.m. The mineral salt, water, and corn and soybean meal based concentrate mixture were provided ad libitum. There was also pasture of Brachiaria decumbens $\mathrm{cv}$. Basilisk grass available in the experimental plot.

Focal animal sampling method was used for data collection thrice a day (12 hours observation a day): in the morning from 08:00 a.m. to 12:00 p.m., in the afternoon from 02:00 p.m. to 06:00 p.m., and at night from 07:00 p.m. to 11:00 p.m. The sampling method was adapted from Martin and Bateson (1986). Data on the behavior of each animal were continuously recorded (using the ethogram) by properly trained animal observers positioned at $8 \mathrm{~m}$ distance from the calf to avoid casual human / animal interaction and the influence on the animals natural behavior (Table 1). 
Table 1. Ethogram used in the experimente.

Description: focal animal sampling method

\begin{tabular}{ll}
\hline Activity & Activity details \\
\hline Concentrate intake & To place the head in the feeder and consume the diet. \\
Foraging & To collect the food with the mouth in the pasture. \\
Rumination & $\begin{array}{l}\text { The repetitive regurgitation of food, which is then partially or completely reswallowed or } \\
\text { rechewed. }\end{array}$ \\
Leisure & With no apparent activity, standing or lying. \\
Shadow & Period of time in which the animal remained in the shadow. \\
Sun & Period of time in which the animal remained in the sun. \\
Playing 1 & Animals playing to each other, promoting social interaction. \\
Playing 2 & Playing activities toward inanimate objects. \\
Walking & Slow locomotion. \\
Stereotypy & Time spent by the animal performing repetitive behaviors. \\
Water intake & To place the head in the drinking fountain and consume water. \\
Vocalization & Emission of sounds with no apparent meaning. \\
Posture & An upright position and supported only by the feet, not moving. \\
Prone position & Animal with its ventral side against the ground. \\
Lateral decubitus & Position in which the animal lies on its side. \\
\hline
\end{tabular}

Source: Authors.

The Analysis of Variance was run for data on the animal behavior by means of the generalized linear model, considering the log-normal distribution for variables expressed in minutes, and the negative binomial distribution for variables expressed in frequency. Treatment averages were compared by Tukey's test at 5\% probability. The SAS statistical software (Statistical Analisys System, 2010) was used for data analyses.

\section{Results}

The time recommended for behavioral observations allowed detecting the period in which animals spent less time in the concentrate intake. Table 2 shows that calves remained more time in the concentrate intake activity in the morning and in the afternoon. The foraging behavior varied among the shifts studied $(\mathrm{P}<0.05)$, where greater activity was recorded in the dayshift (in the morning and in the afternoon), and a decrease was recorded at night (Table 2). 
Table 2. Intake behavior of calves according to the shift (morning, afternoon and night).

Shift

\begin{tabular}{|c|c|c|c|c|c|}
\hline & Concentrate intake ${ }^{1}$ & Water intake ${ }^{2}$ & Leisure $^{1}$ & Foraging $^{1}$ & Rumination $^{1}$ \\
\hline Morning & $15.25 \mathrm{a}$ & $2.96 \mathrm{a}$ & $100.88 \mathrm{a}$ & $85.66 \mathrm{a}$ & $38.20 \mathrm{~b}$ \\
\hline Afternoon & $15.36 \mathrm{a}$ & $2.10 \mathrm{a}$ & $99.33 \mathrm{a}$ & $88.53 \mathrm{a}$ & $36.76 b$ \\
\hline Night & $5.20 \mathrm{~b}$ & - & $65.51 \mathrm{a}$ & $68.73 b$ & $65.51 \mathrm{a}$ \\
\hline
\end{tabular}

Averages followed by the same letter in the column do not differ to each other by Tukey test $(\mathrm{P}<0.05)$.

${ }^{1}$ values expressed in minutes; ${ }^{2}$ values expressed in frequency.

- unquantified values.

Source: Authors.

No differences were found either for leisure or water intake in the shifts studied $(\mathrm{P}>0.05)$. Significant differences were found for rumination between shifts $(\mathrm{P}<0.05)$ (Table 2), and animals ruminated for much time at night regardless the animal age.

The animal search for shadow and sun did not differ between shifts $(\mathrm{P}>0.05)$, as well as the position in which animals lay, whether it was the prone position or lateral decubitus. Animals remained in the standing position for longer in the afternoon, and they were motivated to walk in the morning, since they remained standing in the upright position in the afternoon, not moving (Table 3).

Table 3. Thermoregulation behavior according to the shift (morning, afternoon and night).

\begin{tabular}{lccccc} 
Shift & Shadow $^{1}$ & Sun $^{1}$ & Standing $^{1}$ & Prone position $^{1}$ & Lateral decubitus $^{1}$ \\
\hline Morning & $122.80 \mathrm{a}$ & $117.20 \mathrm{a}$ & $123.73 \mathrm{~b}$ & $113.73 \mathrm{a}$ & $2.53 \mathrm{a}$ \\
Afternoon & $116.63 \mathrm{a}$ & $123.36 \mathrm{a}$ & $127.70 \mathrm{a}$ & $110.70 \mathrm{a}$ & $1.60 \mathrm{a}$ \\
Night & - & - & $99.73 \mathrm{c}$ & $136.80 \mathrm{a}$ & $3.46 \mathrm{a}$ \\
\hline
\end{tabular}

Averages followed by the same letter in the column do not differ to each other by Tukey test $(\mathrm{P}<0.05)$

1 values expressed in minutes.

- unquantified values.

Source: Authors.

Table 4 shows that animals stayed for much time walking in the morning. Besides, statistical differences were found between the playing interaction 1 and the playing interaction $2(\mathrm{P}<0.05)$, according to shifts assessed. Stereotyped behaviors (sucking another animal's prepuce, nibbling the chain and the steel wire) did not differ between the shifts ( $\mathrm{P}>0.05)$. Calves found themselves motivated to show this behavior in the afternoon and at night. There were no significant differences $(\mathrm{P}>0.05)$ regarding vocalization between shifts (Table 5). 
Table 4. Locomotion behavior and stereotypes of dairy calves according to the shift (morning, afternoon and night).

\begin{tabular}{lcccc} 
Shift & Walking $^{1}$ & ${\text { Playing } 1^{1}}$ & Stereotypy $^{1}$ & ${\text { Playing } 2^{1}}^{1}$ \\
\hline Morning & $216.58 \mathrm{a}$ & $3.43 \mathrm{~b}$ & $12.95 \mathrm{a}$ & $7.03 \mathrm{~b}$ \\
Afternoon & $162.35 \mathrm{~b}$ & $9.76 \mathrm{a}$ & $30.46 \mathrm{a}$ & $37.41 \mathrm{a}$ \\
Night & $49.80 \mathrm{~b}$ & $7.86 \mathrm{a}$ & $4.10 \mathrm{a}$ & $18.23 \mathrm{a}$ \\
\hline
\end{tabular}

Averages followed by the same letter in the column do not differ to each other by Tukey test $(\mathrm{P}<0.05)$.

${ }^{1}$ values expressed in minutes.

Source: Authors.

Table 5. Vocalization behavior with no apparent meaning, according to the shift (morning, afternoon and night).

\section{Shift}

\section{Vocalization $^{2}$}

$\begin{array}{lr}\text { Morning } & 0.73 \mathrm{a} \\ \text { Afternoon } & 2.46 \mathrm{a} \\ \text { Night } & 0.43 \mathrm{a}\end{array}$

Averages followed by the same letter in the column do not differ to each other by Tukey test $(\mathrm{P}<0.05)$.

2 values expressed in frequency.

Source: Authors.

\section{Discussion}

The findings in this study show that animals were in a good state of welfare, since the foraging occurred either in the morning or in the afternoon, and the rumination occurred more frequently during the night. This show that animals had normal behavior; the environmental temperature was comfortable and did not interfere in the animal feeding, since high temperatures during the day forces animals to search for shadow.

The lack of significant differences regarding vocalization between shifts was also described as an indicator for good animal welfare, since it indicated that animals did not show differences in vocalization for shifts assessed. According to Zanine et al. (2007), the Brachiaria decumbens species has low ratio blade $\div$ stem, what explains the most selective behavior of calves, reduces the frequency of mouthful uptake, and contributes to the increase in time spent for animal pasturage.

The temperature during the assessment period remained mild, the reason why there were no changes in the water intake during the day. According to Issakowicz et al. (2020), the heat is retained by the atmospheric water vapor and increases the thermal sensation of heat for animals, and also the water intake. The animal water intake usually aims at dissipating the heat when the animal is in a heat stress condition. However, such did not happen in this study, since either the feeding or the rumination occurred in the common time, did not go away from normal, and there were no differences regarding water intake between shifts.

Unlike that, Façanha et al. (2011) studied the behavior of dairy calves and found that animals ingested more water in the warm period, between 12:00 p.m. and 02:00 p.m. This may indicate the animals attempt to lose heat, since they demanded for much water in the warmer period of the day.

The animal's constant activity, assessed by the foraging behavior, concentrate intake and rumination in the day and 
night shifts, contributed to shorten the leisure time. According to Zanine et al. (2007), calves remained greater time at the leisure time in the night shift, specifically from 10:00 p.m. to 01:00 a.m., and from 04:00 a.m. This statement support findings from this study, since observations were carried out at night until 11:00 p.m.

The animal leisure is usually shown more frequently in the quietest times, with mild temperatures across the study area. According to Zanine et al. (2007), animals usually spend most part of the available time foraging, and this activity is reduced at night since animals spent time ruminating and also in the leisure.

Oliveira et al. (2007) mentioned that animals with access to the grazing area usually start pasturing in the first and in the second week of life. This event marks the beginning of the development process of the rumen - reticulum, which reaches the proportion of the adult individual about eight weeks age and marks the transition from the pre-ruminant phase to the ruminant phase.

During the observation period, the weather remained cloudy throughout the day with $25.5^{\circ} \mathrm{C}$ average temperature. According to Bond et al. (2012), animals do not need changing their behavior, aiming at adjusting the body temperature when this ranges within ideal limits for animal thermal comfort, which are between $10^{\circ} \mathrm{C}$ and $30^{\circ} \mathrm{C}$.

Animals use special mechanisms to regulate the body temperature when they feel thermal discomfort and, depending on how the animal lies, the posture may increase or reduce the contact area that affects the rate of heat transfer from the animal to the environment or from the environment to the animal (Almeida et al., 2020). According to Degasperi et al. (2003), cows may lay on lateral decubitus or prone position, and the time they last in a position depends on the type of the facility, the existing comfort in the location, the climate factors, among other factors.

Mac-Lean et al. (2011) stated that animals usually express behaviors that contribute to a prolonged loss of the exceeding heat from the body in tropical climates where temperatures are usually high. Such behaviors may be staying at the standing up position, not moving or ruminating, mechanisms that help animals in the maintenance process of body homeostasis.

Animals can transfer heat from the body to the environment from two different ways: (i) sensible heat transfer that occurs by convection, conduction and radiation; and (ii) the latent heat transfer, which occurs when the temperature increases, by sweating or by increasing the respiratory frequency, and is influenced by the air humidity and also by the temperature, according to Souza and Batista (2012). The temperature control is essential for keeping animals in a good state of welfare, since the heat stress can influence many other activities (Almeida et al., 2020).

Healthy animals are usually motivated to do different behavioral activities, such as by walking, also exercising the paws and improving blood circulation. According to Façanha et al. (2011), one of essential factors to be taken into consideration when dealing with calves in the development stage is the need for sufficient physical space for mobility.

Animals were motivated to move from a place to another, mainly in the morning and in the afternoon, even when were in permanent contact with nearby animals. According to Campos and Campos (2004), animals usually interact to each other, thus stimulating the learning and the early consumption of solid foods. According to Bond et al. (2012), the grouping of calves in small lots contributes to reduce the animal stress caused by socialization and lucid behavior.

The stereotyped behaviors did not show any effect, likely because they were not sufficiently expressive during the observation period. Such behaviors were mostly associated with restrictive conditions of the breeding environments.

According to Bittar et al. (2009), experimental evidences show that the stereotyped behavior of the cross-feeding may occur when animals are housed collectively, and the occurrence of this behavior before and during the weaning process may depends on the amount of ingested milk or energy, as well as can be affected by the weaning method used.

According to Broom and Molento (2004), animals that show behaviors indicative of self-mutilation, stereotypes, overly aggressive behavior; are usually found to be in a bad state of welfare. 
Findings from the lucid behavior show that animals are more motivated to play individually in the afternoon and at night. According to Façanha et al. (2011), animals bred in individual shelters with about $28.2 \mathrm{~m}^{2}$ external area available, appear to have greater freedom of movement. However, calves bred in masonry shelters (individual stalls), with limited space, tend to have a locomotor-rotational movement, occasionally changing this social behavior by other, such as kicks or jumps.

Even after verifying higher frequencies in the emission of sounds when the liquid feeding schedules were approaching, Bond et al. (2012), stated that when the food is provided in limited quantities, animals tend to show behaviors that indicate chronic hunger, expressed by the increase of screams, i.e., vocalizations from calves, that usually cause a decrease in other activities such as playing.

Vocalization measures can be indicative of stress, fear, pain, among other effects. Silva (2007) estimated the stress condition of her-calves in breeding stalls using a measure of vocalization. Results on severe frequency peak were divided into two groups: elder her-calves (47 and 22 days) and younger her-calves (3 days). Averages on frequency peaks bellow and over $7 \mathrm{kHz}$ recorded during the experiment where then calculated. Findings showed that there were no significant differences among peak noise incidences, although the younger her-calves maintained their vocalization for longer than the elder hercalves. In this study, no significant differences were found $(\mathrm{P}>0.05)$ on vocalization; however, a higher frequency was observed in the afternoon due to the supply of liquid food for calves, thus demonstrating a possible state of hunger.

Nascimento et al. (2013) stated that, to characterize whether the animal is or not in a good state of welfare, there are various indicators that can be used, one of them is the observation of animals focusing on behaviors shown under thermal stress, as well as on physiological responses shown by them.

Animal behaviors shown in this study, such as drinking water in different day shifts with no distinction, and foraging either in the morning or in the afternoon, may be used as indicators of good state of welfare; instead, animals would have shown different behaviors. In this study, the animal welfare was, in general, considered good, since behaviors that are usually associated with a bad state of welfare, such as stereotypes, vocalization and luck of playing, did not have any effect in the experiment.

\section{Conclusion}

The behavior of dairy calves of the Girolando breed at 3 months old was evaluated in the following shifts: in the morning, in the afternoon and at night. The intake behavior, the thermoregulation process and the walking activity occurred more frequently in the day-shifts; the social interaction to each other or with inanimate objects in the facilities was prevalent in the afternoon and at night; and the rumination occurred mainly during the night.

\section{Acknowledgments}

The study was developed under the support of the Study Group on Bioclimatology, Ethology and Animal Welfare (BioEt), as well as the Federal University of Paraíba.

\section{References}

Almeida, J. V. N. de, Marques, L. R., Marques, T. C., Guimarães, K. C., \& Leão, K. M. (2020). Influence of thermal stress on the productive and reproductive aspects of cattle. Review. Research, Society and Development, 9(7), e230973837. https://doi.org/10.33448/rsd-v9i7.3837

Bittar, C. M. M., Ferreira, L. S., Santos, F. A. P., \& Zopollatto, M. (2009). Desempenho e desenvolvimento do trato digestório superior de bezerros leiteiros alimentados com concentrado de diferentes formas físicas. Revista Brasileira de Zootecnia, 38(8), 1561-1567. http://dx.doi.org/10.1590/S151635982009000800021

Bond, G. B., Almeida, R. D., Ostrensky, A., \& Molento, C. F. M. (2012). Métodos de diagnóstico e pontos críticos de bem-estar de bovinos leiteiros. Ciência Rural, 42(7), 1286-1293. https://doi.org/10.1590/S0103-84782012005000044 
Broom, D. M., \& Molento, C. F. M. (2004). Bem-estar animal: conceito e questões relacionadas - revisão. Archives of Veterinary Science, 9(2), 1-11. http://revistas.ufpr.br/veterinary/article/view/4057/3287

Campos, O. F., \& Campos, A. T. (2004). Instalações para bezerros de rebanhos leiteiros. http://www.cnpgl.embrapa.br/totem/conteudo/Outros_assunto s/Circular_Tecnica/CT80_Instalacao_para_bezerros_de_rebanhos_leiteiros.pdf

Carneiro, A. C. G., Teixeira, R. M. A., de Paiva, I. F., Silva, P. S. D., Mendes, B. P., Neto, M. C. P. C., \& de Oliveira, L. F. (2020). Avaliação do comportamento ingestivo de bezerros leiteiros submetidos a duas estratégias de aleitamento. Revista do Instituto de Laticínios Cândido Tostes, 75(2), 72-82. https://doi.org/10.14295/2238-6416.v75i2.793

Degasperi, S. A. R., Coimbra, C. H., Pimpão, C. T., Souza, F. P., Cbi, K. D., Glaser Junior, P., Ernlund, R., Macedo, F., Piekasski, P. R. B., Almeida, R., \& Da Costa, T. S. (2003). Estudo do comportamento do gado Holandês em sistema de semi-confinamento. Revista Acadêmica de Ciências. Agrárias e Ambientais, $1(4), 41-47$.

Façanha, D. A. E., Vasconcelos, A. M., Silva, W. S. T., Chaves, D. F., Morais, J. H. G., \& Olivo, C. J. (2011). Respostas comportamentais e fisiológicas de bezerros leiteiros criados em diferentes tipos de instalações e dietas líquidas. Acta Veterinária Brasílica, 5(3), $250-257$. http://dx.doi.org/10.21708/avb.2011.5.3.1814

Issakowicz, A. C. K. S., Toledo, L. M., \& Ambrosio, L. A. (2020). Dinâmica do sistema de criação de bezerras no período de aleitamento: modelo conceitual. Boletim De Indústria Animal, 77, 1-19. https://doi.org/10.17523/bia.2020.v77.e1465

Mac-Lean, P. A. B., Barbosa, O. R., Jobim, C. C., Gasparino, E., Santos, G. T., \& Faria, L. A. N. (2011). Sombra artificial e método de fornecimento de concentrado no comportamento e desempenho de bezerros desmamados. Acta Scientiarum. Animal Sciences, $33(4)$, 409-415. http://dx.doi.org/10.4025/actascianimsci.v33i4.10672

Martin, P., \& Bateson, P. (1986). Measuring Behaviour: An Introductory Guide: Third Edition.

Nascimento, G. V., Cardoso, E. A., Batista, N. L., Souza, B. B., \& Cambuí, G. B. (2013). Indicadores produtivos, fisiológicos e comportamentais de vacas de leite. Agropecuária Cientifica no Semiárido, 9(4), 15-28. http://dx.doi.org/10.30969/acsa.v9i4.349

Oliveira, A. A., Azevedo, H. C., \& Melo, C. B. Criação de Bezerras em Sistemas de Produção de Leite. (2005). Embrapa Tabuleiros Costeiros. Circular Técnica. http://www.cpatc.embrapa.br/publicacoes_2005/ct-38.pdf (accessed 10 December 2019).

Oliveira, J. S., Zanine, A. M., \& Santos, E. M. (2007). Fisiologia, manejo e alimentação de bezerros de corte. Arquivos de Ciências Veterinárias e Zoologia da UNIPAR, 10(1), 39-48.

SAS, SAS ${ }^{\circledR}$ User's guide: Statistics. (2010). Version 9.1 Edition. SAS Institute Inc., Cary NC, USA.

Silva, R. A. (2007). Reconhecimento de estresse em bezerro utilizando medida de vocalização/assessment of stress in calfusing vocalization measurement. Revista Brasileira de Engenharia de Biossistemas, 1(3), 219-225. http://dx.doi.org/10.18011/bioeng2007v1n3p219-225

Souza, B. B., \& Batista, N. L. (2012). Os efeitos do estresse térmico sobre a fisiologia animal. Agropecuária Científica no Semiárido, 8(3), 15-28.

Svensson, C., \& Jensen, P. (2007). Short communication: Identification of diseased calves by use of data from automatic milk feeders. Journal of Dairy Science, 90, 994-997. http://dx.doi.org/10.3168/jds.S0022-0302(07)71584-9

Von Keyserlingk, M. A. G., Rushen, J., Passillé, A. M., \& Weary, D. M. (2009). Invited review: The welfare of dairy cattle-Key concepts and the role of Science. Journal of Dairy Science, 92(9), 4101-4111. http://dx.doi.org/10.3168/jds.2009-2326

Zanine, A. M., Santos, E. M., Parente, H. N., Ferreira, D. J., \& Cecon, P. R. (2007). Hábito de pastejo de vacas lactantes Holandês x Zebu em pastagem de Brachiaria brizantha e Brachiaria decumbens. Arquivos Brasileiro de Medicina Veterinária e Zootecnia, 59(1), $175-181$. 